\title{
White-nose syndrome detected in bats over an extensive area of Russia
}

\author{
Veronika Kovacova ${ }^{1 *} \mathbb{D}$, Jan Zukal ${ }^{2,3}$, Hana Bandouchova' ${ }^{1}$, Alexander D. Botvinkin ${ }^{4}$, Markéta Harazim², \\ Natália Martínková, ${ }^{2,5}$, Oleg L. Orlov ${ }^{6,7}$, Vladimir Piacek ${ }^{1}$, Alexandra P. Shumkina ${ }^{8}$, Mikhail P. Tiunov ${ }^{9}$ and Jiri Pikula ${ }^{1}$
}

\begin{abstract}
Background: Spatiotemporal distribution patterns are important infectious disease epidemiological characteristics that improve our understanding of wild animal population health. The skin infection caused by the fungus Pseudogymnoascus destructans emerged as a panzootic disease in bats of the northern hemisphere. However, the infection status of bats over an extensive geographic area of the Russian Federation has remained understudied.

Results: We examined bats at the geographic limits of bat hibernation in the Palearctic temperate zone and found bats with white-nose syndrome (WNS) on the European slopes of the Ural Mountains through the Western Siberian Plain, Central Siberia and on to the Far East. We identified the diagnostic symptoms of WNS based on histopathology in the Northern Ural region at $11^{\circ}$ (about $1200 \mathrm{~km}$ ) higher latitude than the current northern limit in the Nearctic. While body surface temperature differed between regions, bats at all study sites hibernated in very cold conditions averaging $3.6^{\circ} \mathrm{C}$. Each region also differed in $P$. destructans fungal load and the number of UV fluorescent skin lesions indicating skin damage intensity. Myotis bombinus, M. gracilis and Murina hilgendorfi were newly confirmed with histopathological symptoms of WNS. Prevalence of UV-documented WNS ranged between 16 and $76 \%$ in species of relevant sample size.
\end{abstract}

Conclusions: To conclude, the bat pathogen P. destructans is widely present in Russian hibernacula but infection remains at low intensity, despite the high exposure rate.

Keywords: Chiroptera, Hibernation, Pseudogymnoascus destructans, Prevalence, Distribution

\section{Background}

Any infectious disease determinants associated with the host(s), the agent and the environment will vary geographically [1]. Geographic distribution of infectious diseases is modulated by climate-associated factors inducing changes in the host-pathogen system [2-4]. Variation in the host-pathogen system attributable to climate includes changes in virulence, adaptation of the pathogen to hosts and vectors, the pathogen's ability to survive in the environment after being shed from the host, along with host population ecology, susceptibility and immune function [5]. Generally speaking, anthropogenic, environmental and ecological factors are drivers of infectious disease emergence [6]. Spatial and temporal distribution data related to infectious diseases are

\footnotetext{
* Correspondence: kovacovav@vfu.cz

${ }^{1}$ Department of Ecology and Diseases of Game, Fish and Bees, University of Veterinary and Pharmaceutical Sciences Brno, Palackého tř. 1946/1, 61242 Brno, Czech Republic

Full list of author information is available at the end of the article
}

necessary to increase our understanding of population health in wild animals, to identify populations and species at risk, to trace disease origin, to predict and model disease spread and dynamics and to propose effective control measures.

While bats have been recognised as important reservoir hosts for a great variety of emerging infectious agents [7], the fungus Pseudogymnoascus destructans [8, 9], causative agent of white-nose syndrome (WNS), is the first pathogen to threaten chiropteran biodiversity $[10,11]$ in the temperate zone. Constrained by temperature [12] and humidity [13], WNS emerged in a specific niche, i.e. underground bat hibernacula [14]. Breaking out as a point epidemic in eastern North America in 2006 [10], $P$. destructans infection has gradually been recognized as a panzootic in bats of the northern hemisphere [10, 15-21].

Success in WNS surveillance depends on the use of accurate tools and timing of sampling, along with knowledge on the seasonality and natural history of the disease. In addition to qualitative fungus identification 


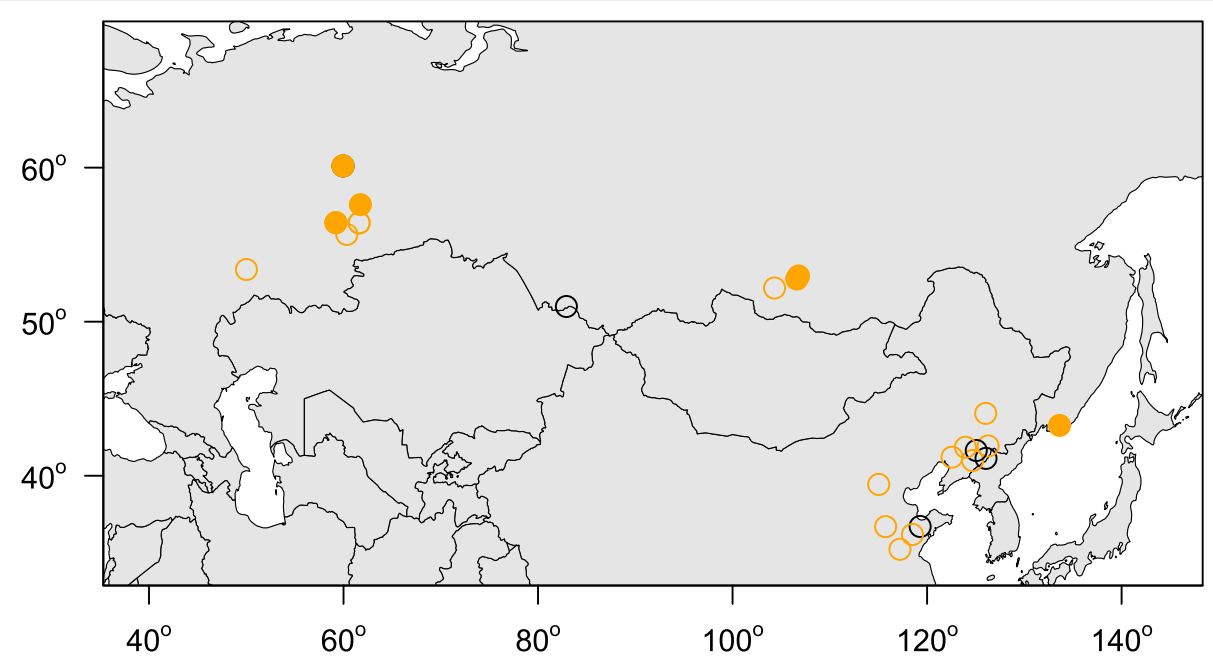

Fig. 1 Distribution of study sites in the central and eastern parts of the Russian Federation. Closed circles $=$ this study, open circles = previously published sites $[21,28]$, orange $=$ Pseudogymnoascus destructans infection confirmed with quantitative $P C R$, black $=P$. destructans not detected

using culture and polymerase chain reaction (PCR) [8], quantitative methods such as qPCR [22] and image analysis of photographs taken via trans-illumination of wing membranes with UV light [23] can also be used to evaluate infection intensity [21]. In fact, modification of the Wood's lamp for UV light diagnostics of WNS is one of the most useful tools allowing immediate recognition of infected bats, the method being highly sensitive and specific in targeting skin lesions for biopsy collection under field conditions. As UV lamp is a non-lethal diagnostic tool allowing rapid examination, it is applicable for the examination of protected bat species. UV transillumination also allows the researcher to distinguish between invasive infection and skin surface colonisation in $P$. destructans-exposed bats $[24,25]$ as it functions by fluorescing skin lesions laden with vitamin $\mathrm{B}_{2}$, that are characteristic of $P$. destructans infection [26].

WNS skin infection has recently been recognised in the West Siberian Plain of Russian Asia [21] and north-eastern China [19]. Widespread endemicity of the WNS fungus in the Palearctic suggests that bat tolerance to this infection probably became established due to long-term co-evolution [21, 27]. Interestingly, presence of the pathogen has also been identified in historic bat populations and the regions of Samara and Irkutsk (European and Asian parts of Russia, respectively) using ethanol-stored samples of bat ectoparasites [28]. Here we further address the infection status of bats over an extensive geographic area of Russia, extending the known northern and eastern geographic limits of the disease and detailing site- and species-dependent differences in epidemiological characteristics.

\section{Methods}

Bat sampling sites and procedures

Between 2014 and 2017 we sampled 188 bats (11 species) at 11 hibernation sites from the European slopes of the Ural Mountains through the Western Siberian Plain, Siberia and the Russian Far East (Fig. 1; Table 1). Bats were sampled during the late hibernation season (April and May) and all bats were later released at the capture site. Bat body temperature was measured individually with a Raynger MX2 non-contact IR thermometer (Raytek Corporation, USA) by focusing the laser beam at the central part of bat's body. Following hand capture, the

Table 1 Number of bats sampled in Russia

\begin{tabular}{lllll}
\hline Species & \multicolumn{2}{l}{ Gender } & Total \\
\cline { 2 - 4 } & Females & Males & NA & \\
\hline Eptesicus nilssonii & 9 & 22 & 31 \\
Myotis bombinus & 1 & 2 & 1 & 3 \\
Myotis brandtii & 7 & 11 & 19 \\
Myotis dasycneme & 30 & 19 & & 49 \\
Myotis daubentonii & 1 & 2 & 3 \\
Myotis gracilis & 2 & 32 & 34 \\
Myotis macrodactylus & 1 & & 1 \\
Myotis petax & 2 & & & 2 \\
Murina hilgendorfi & 19 & 17 & & 36 \\
Plecotus auritus & & 1 & 1 & 9 \\
Plecotus ognevi & & 106 & 2 & 188 \\
Total & 80 & & & 1 \\
\hline
\end{tabular}

Gender and species data were obtained for bats included in the study. While each bat was sexed by inspection of external genitalia, species identification was based on morphological traits and/or sequencing the mitochondrial gene for cytochrome $b$ (mtcyb) 
Table 2 Differences in bat communities, hibernation temperature and infection status between sites

\begin{tabular}{|c|c|c|c|c|c|c|c|}
\hline Region & Locality & Number of bats & $\begin{array}{l}\text { Number } \\
\text { of species }\end{array}$ & $\begin{array}{l}\text { WNS UV } \\
\text { lesions }\end{array}$ & $\begin{array}{l}\text { WNS qPCR } \\
\text { assay }\end{array}$ & $\begin{array}{l}\text { WNS } \\
\text { histo-positivity }\end{array}$ & $\begin{array}{l}\text { Median } \\
\text { temperature }\left({ }^{\circ} \mathrm{C}\right)\end{array}$ \\
\hline Southern Ural & Slyudorudnik mine & 12 & 4 & + & + & + & 3.95 \\
\hline \multirow[t]{3}{*}{ Middle Ural } & Arakaevskaja cave & 10 & 2 & + & + & + & 1.25 \\
\hline & Smolinskaja cave & 21 & 3 & + & + & + & 4.70 \\
\hline & Šajtanskaja cave & 25 & 4 & + & + & - & 1.40 \\
\hline \multirow[t]{3}{*}{ Northern Ural } & Dačnaja cave & 1 & 1 & - & - & - & 3.50 \\
\hline & Komsomolskaja cave & 18 & 3 & + & + & + & 2.70 \\
\hline & Partizanskaja cave & 16 & 2 & + & + & + & 3.45 \\
\hline \multirow[t]{3}{*}{ Baikal } & Aja cave & 2 & 1 & N.A. & + & N.A. & N.A. \\
\hline & Mečta cave & 31 & 3 & + & + & + & 1.00 \\
\hline & Cave Vologodskovo & 10 & 1 & + & + & + & 4.70 \\
\hline Far East & Primorskij Velikan cave & 42 & 5 & + & + & + & 4.40 \\
\hline \multicolumn{4}{|c|}{ Total number of positive bats } & 78 & 135 & 48 & \\
\hline
\end{tabular}

Apart from hibernation conditions (body surface temperature of bats), the table includes data concerning bat biodiversity and qualitative measures of Pseudogymnoascus destructans infection status

dorsal side of the left wing was swabbed with a nylon swab (FLOQ Swabs, Copan Flock Technologies srl, Brescia, Italy) for qPCR diagnosis. Presence and quantity of $P$. destructans was assessed using a TaqMan ${ }^{\circ}$ Universal Master Mix II with UNG (Life Technologies, Foster City, CA, USA) using the dual-probe assay [22]. Optimisation of the PCR reaction and calculation of fungal load was in accordance with Zukal et al. [21] for samples taken between 2014 and 2016 and Zahradníková et al. [28] for samples from 2017. The diagnostic symptoms of WNS were confirmed by current standards. For histopathology analysis, we selected orange-yellow fluorescing spots observed over a $368 \mathrm{~nm}$ UV lamp [23]. Suspect wing tissues were biopsied and stored in $10 \%$ formalin. The

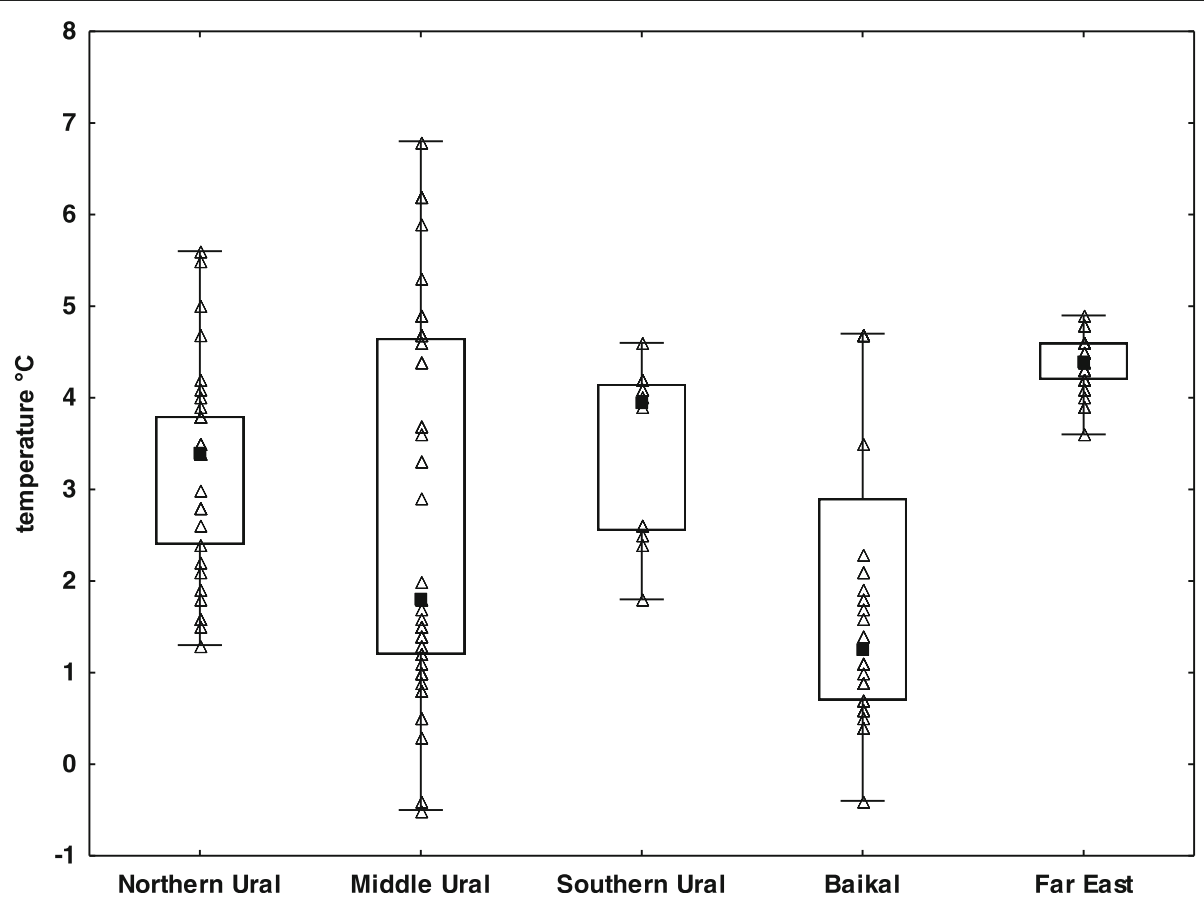

Fig. 2 Body temperature of hibernating bats in the study regions. Explanation: black square mid-point = median; box=inter-quartile range; whiskers $=$ minimum $/$ maximum range, empty triangles $=$ particular samples 
formalin-fixed skin samples were then embedded in paraffin and stained for fungi with periodic acid-Schiff stain. Histological observation took place under an Olympus BX51 light microscope (Olympus Corporation, Tokyo, Japan). Yellow-orange fluorescing WNS lesions on the right wing were manually enumerated on trans-illuminated photographs using the ImageJ counting tool [29].

\section{Phylogenetic reconstruction}

We sequenced the mitochondrial gene for cytochrome $b$ (mtcyb) in 77 bats in order to validate species identification in newly sampled regions. DNA was isolated from the wing punch biopsies using the DNeasy Blood \& Tissue Kit (Qiagen, Halden, Germany), according to the manufacturer's protocol. We amplified the mtcyb gene with the

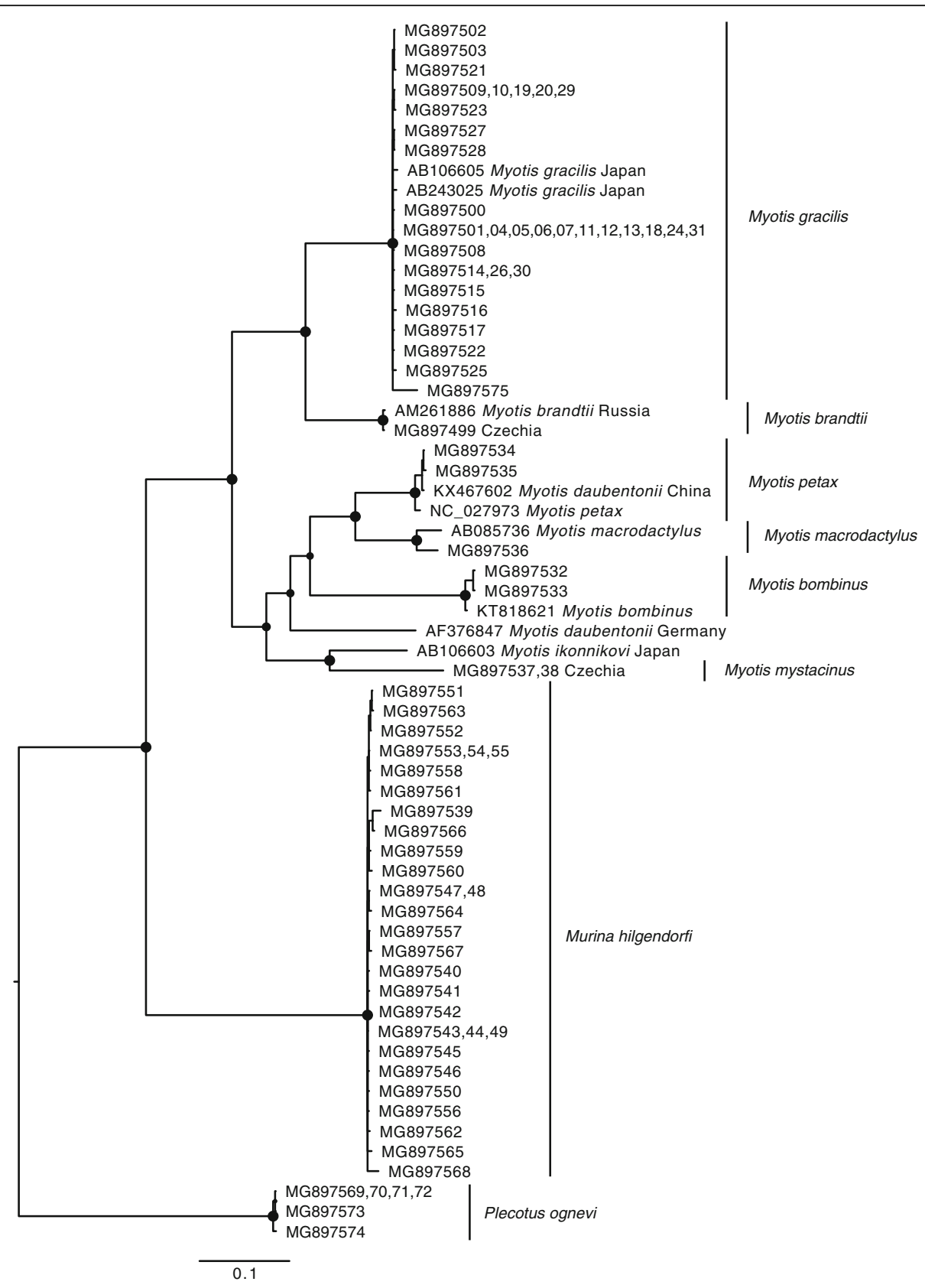

Fig. 3 Bayesian inference phylogeny of bats from the Eastern Palearctic based on partial mtcyb gene sequences. Circles at nodes indicate Bayesian posterior probability $>0.95$; species reported in this study are indicated with vertical bars. Specimen vouchers are listed for newly sequenced individuals, where numbers in curly brackets represent multiple vouchers. Previously published sequences are reported with their accession numbers, species designation in GenBank and country of sample origin 
mammalian primers L7 (ACCAATGACATGAAAAATC ATCGTT) and H6 (TCTCCATTTCTGGTTTACA AGAC) [30], supplied at $0.2 \mu \mathrm{M}$ concentration in a reaction mix containing $1 \times$ buffer, $0.2 \mathrm{mM}$ of dNTPs, $2 \mathrm{mM}$ $\mathrm{MgCl}_{2}$ and $0.1 \mathrm{U}$ Platinum Taq polymerase (Invitrogen, Life Technologies, Carlsbad, CA, USA). The cycling conditions included a 3 min denaturation step at $95{ }^{\circ} \mathrm{C}$, followed by 36 cycles of $40 \mathrm{~s}$ at $95{ }^{\circ} \mathrm{C}, 50 \mathrm{~s}$ at $53{ }^{\circ} \mathrm{C}$ and $80 \mathrm{~s}$ at $72{ }^{\circ} \mathrm{C}$. The reaction was finalised with a $3 \mathrm{~min}$ extension at $72{ }^{\circ} \mathrm{C}$. We purified the PCR products through EXO-CIP enzymatic purification and sequenced them commercially with amplification primers from both directions. The chromatograms were assembled in CodonCode Aligner 7.1 (CodonCode, Centerville, MA, USA). Together with mtcyb sequences from GenBank, we aligned the sequences in MAFFT 7.3 [31] and reconstructed the phylogenetic relationships in MrBayes 3.2 [32] using Markov chain Monte Carlo (MCMC) sampling over two independent runs. The MCMC used the HKY $+\Gamma$ substitution model run for 1 million generations with $30 \%$ of initial sampled states discarded as burn in. The settings enabled MCMC convergence and trees in the posterior were summarised with $50 \%$ majority-rule consensus.

\section{Statistical analysis}

The common logarithm of $P$. destructans load and the number of UV-documented skin lesions were used for statistical analysis as these variables did not meet normality (Shapiro-Wilk test, $p<0.05$ ). Differences between regions and bat species were tested using ANOVA. Body surface temperature could not be transformed to normality; hence, non-parametric Kruskal-Wallis ANOVA was used for the comparison of body surface temperature between regions and bat species. Pearson's correlation coefficient was used to evaluate the relationship between $P$. destructans load and the number of UV-identified skin lesions. All analyses were performed using Statistica for Windows 12.0 (StatSoft, USA).

\section{Results}

\section{Locality-dependent differences}

WNS positive bats (both $P$. destructans-positive on qPCR and WNS-positive on UV and histopathology) were confirmed in all study regions (Fig. 1) and at all hibernation sites (Table 2) except the Dachnaya cave, where a single bat was checked with no signs of WNS and negative qPCR results. The sample sites covered the whole of the Asian part of Russia, with additional new sites in the European part. Sites situated in the Northern Ural region were approximately $1200 \mathrm{~km}$ further north than any previous site with confirmed WNS in the world. Bats at all study sites hibernated in very cold climatic conditions (median $3.6{ }^{\circ} \mathrm{C}$, min $-0.5{ }^{\circ} \mathrm{C}$, max $6.8^{\circ} \mathrm{C}$ ), with warmest conditions recorded near the coast at the Primorskiy Velikan cave in the Primorskiy region (Fig. 2). Body surface temperatures differed significantly between regions, with a significant correlation observed between body surface temperature and ambient temperature (Kruskal-Wallis test: $H_{4}, 185=39.35, p<$ 0.001). Regions also differed significantly in $P$. destructans fungal load (ANOVA: $F_{4,130}=17.11, p<0.001$ ) and number of UV fluorescent skin lesions (ANOVA: $F_{4,66}=$ $17.54, p=0.001$ ), with bats hibernating in the Baikal having lowest values of both disease parameters (Table 2).

\section{Differences between species of hibernating bats}

Samples were analysed from 11 bat species covering most of the hibernating bat diversity in the Eastern Palearctic region. Of the 77 bats sequenced (European

Table 3 Prevalence (percentage) with confidence interval of Pseudogymnoascus destructans infection in Russian bats

\begin{tabular}{|c|c|c|c|c|c|c|c|c|c|}
\hline \multirow[t]{2}{*}{ Species } & \multicolumn{4}{|c|}{ WNS UV-documented skin lesions } & \multicolumn{4}{|c|}{ WNS qPCR assay } & \multirow{2}{*}{$\begin{array}{l}\text { Histo- } \\
\text { positivity }\end{array}$} \\
\hline & Negative & Positive & Analyzed & Prevalence & Negative & Positive & Analyzed & Prevalence & \\
\hline Eptesicus nilssonii & 26 & 5 & 31 & $16.1 \pm 12.9$ & 26 & 5 & 31 & $16.1 \pm 12.9$ & + \\
\hline Myotis bombinus & 1 & 1 & 2 & $50.0 \pm 69.3$ & & 3 & 3 & $100.0 \pm 0.0$ & + \\
\hline Myotis brandtii & 10 & 9 & 19 & $47.4 \pm 22.5$ & 7 & 12 & 19 & $63.2 \pm 21.7$ & - \\
\hline Myotis dasycneme & 12 & 37 & 49 & $75.5 \pm 12.0$ & 7 & 41 & 48 & $85.4 \pm 10.0$ & + \\
\hline Myotis daubentonii & 2 & 1 & 3 & $33.3 \pm 53.3$ & 2 & 1 & 3 & $33.3 \pm 53.3$ & N.A. \\
\hline Myotis gracilis & 26 & 7 & 33 & $21.2 \pm 13.9$ & 5 & 29 & 34 & $85.3 \pm 11.9$ & + \\
\hline Myotis macrodactylus & 1 & & 1 & $0.0 \pm 0.0$ & & 1 & 1 & $100.0 \pm 0.0$ & N.A. \\
\hline Myotis petax & & 2 & 2 & $100.0 \pm 0.0$ & & 1 & 1 & $100.0 \pm 0.0$ & + \\
\hline Murina hilgendorfi & 21 & 15 & 36 & $41.7 \pm 16.1$ & & 36 & 36 & $100.0 \pm 0.0$ & + \\
\hline Plecotus auritus & & 1 & 1 & $100.0 \pm 0.0$ & & 1 & 1 & $100.0 \pm 0.0$ & + \\
\hline Plecotus ognevi & 7 & & 7 & $0.0 \pm 0.0$ & 3 & 5 & 8 & $62.5 \pm 33.5$ & N.A. \\
\hline Total & 106 & 78 & 184 & & 50 & 135 & 185 & & 8 species \\
\hline
\end{tabular}




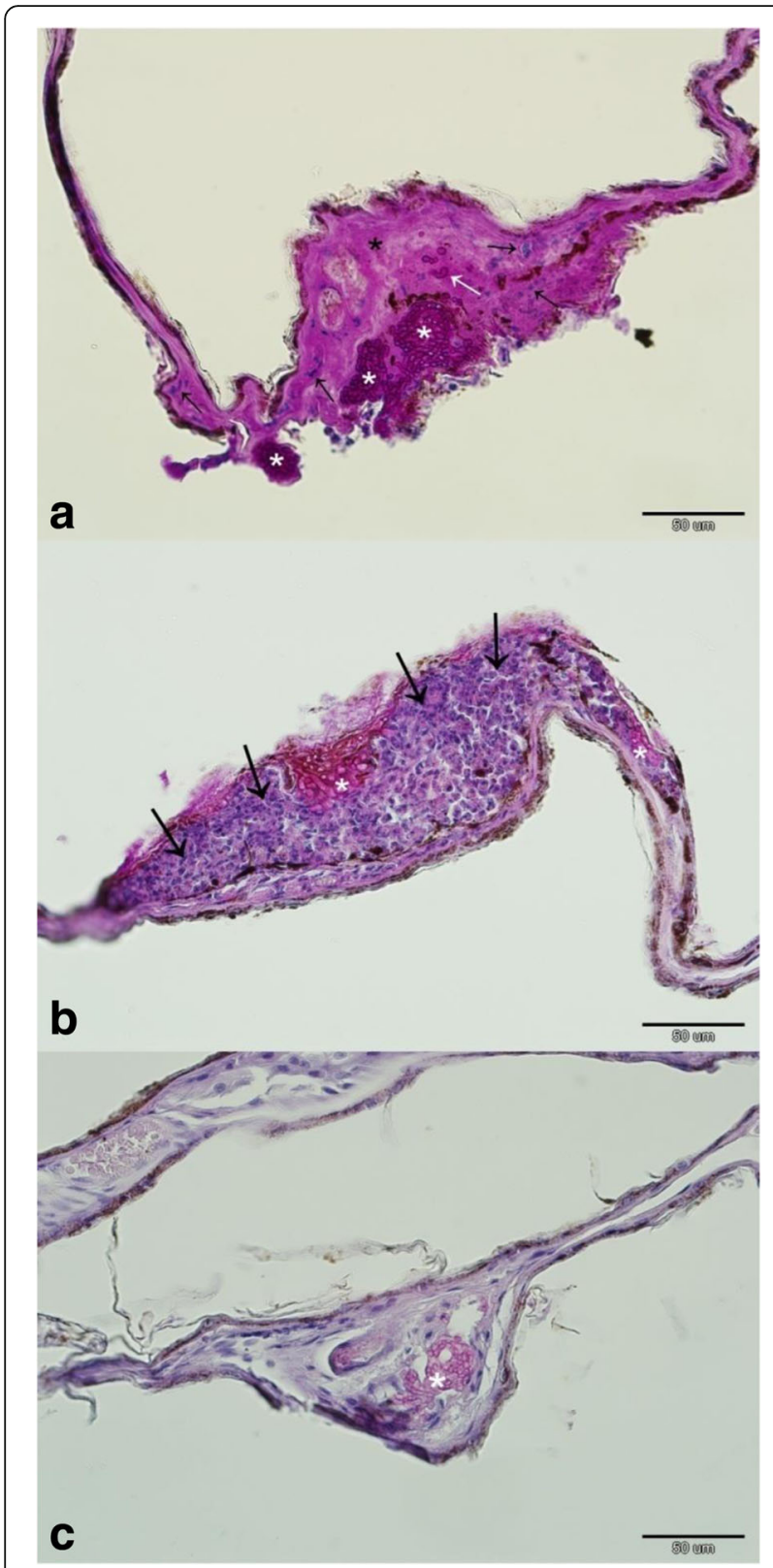

Fig. 4 Dermatopathology of Pseudogymnoascus destructans infection in Russian bats. a Myotis dasycneme, Urals: necrotic wing membrane characterised by loss of skin structure and hypereosinophilia (black asterisk), cupping erosions packed with $P$. destructans hyphae (white asterisk) breaching the basement membrane (white arrow),

neutrophilic inflammation (black arrow). b Myotis gracilis, Baikal: fungal cupping erosions (white asterisk) sequestered with neutrophils (black arrow) from the wing membrane. c Murina hilgendorfi, Primorye: hair follicle (white asterisk) and associated glands infected with the fungus. Periodic acid-Schiff stain

Nucleotide Archive: MG897500 - MG897575), 25 were identical to others in the dataset. We added nine previously published sequences in order to obtain an alignment containing 60 unique haplotypes of partial mtcyb sequences 1061 bp long. Using Bayesian inference phylogenetic reconstruction (Fig. 3), we confirmed that bat genetic diversity based on the mtcyb gene is consistent with known bat diversity in the Eastern Palearctic.

With the exception of Myotis macrodactylus and Plecotus ognevi, where only $P$. destructans DNA material was found on the wings, all the bat species monitored were confirmed as both $P$. destructans and WNS positive (Table 3). Three bat species (M. bombinus, M. gracilis and Murina hilgendorfi) are newly confirmed with WNS histopathological symptoms identical with those shown by European and North American bats (Fig. 4). Prevalence of P. destructans infection (qPCR) and WNS (expressed as UV fluorescent skin lesions) varied between species (Table 3), with WNS prevalence ranging between 16 and $76 \%$ in samples with more than five specimens. Similarly, both WNS impact parameters, i.e. $P$. destructans load (ANOVA: $F_{8,126}=9.41$, $p<0.001$; Additional file 1: Figure S1 and Fig. 5) and number of UV fluorescent skin lesions (ANOVA: $F_{7,63}=3.32, p$ $=0.005$ ) differed significantly between bat species. There was also a significant correlation between fungal load and number of UV fluorescent skin lesions $(r=0.40, p<0.05)$.

\section{Discussion}

Russia's enormous size and the geographic remoteness of many hibernacula makes active surveillance for bat diseases a difficult task in the Eastern Palearctic. The resulting poor knowledge of bat community infection status over such an extensive understudied territory means that impacts of wildlife conservation concern often go undetected. Further, while single visits to hibernation sites provide static data, they cannot evaluate disease dynamics or changes in bat abundance. However, long-term monitoring of hibernating bats in caves in the study regions have yet to report any mass mortalities or dramatic declines in bat abundance [33-36].

Since 2008, presence of $P$. destructans and/or WNS has been confirmed over an area stretching from Portugal to Turkey $[17,18,37,38]$. By extending our knowledge on the distribution range of $P$. destructans to the Northern Ural region (forming the boundary between the European and Asian continents) and on to the southern part of the Russian Far East, we come close to covering the geographic limits of bat hibernation in the Palearctic temperate zone [21, 39-41]. In light of current data, the last remaining biogeographic questions regarding WNS distribution in the Palearctic are its presence or absence in Japan, Sakhalin, the Kuril Islands or the Kamchatka Peninsula. Based on its presence in both Continental Europe and the British Isles [42], it is quite likely that $P$. destructans will be found in islands off the mainland of Far Eastern Asia. Furthermore, we were able to confirm histopathological symptoms of WNS (Fig. 4a; [24, 43]) in bats at an $11^{\circ}$ (ca. $1200 \mathrm{~km}$ ) higher latitude than the previous highest finding in the Canadian provinces [44]. 


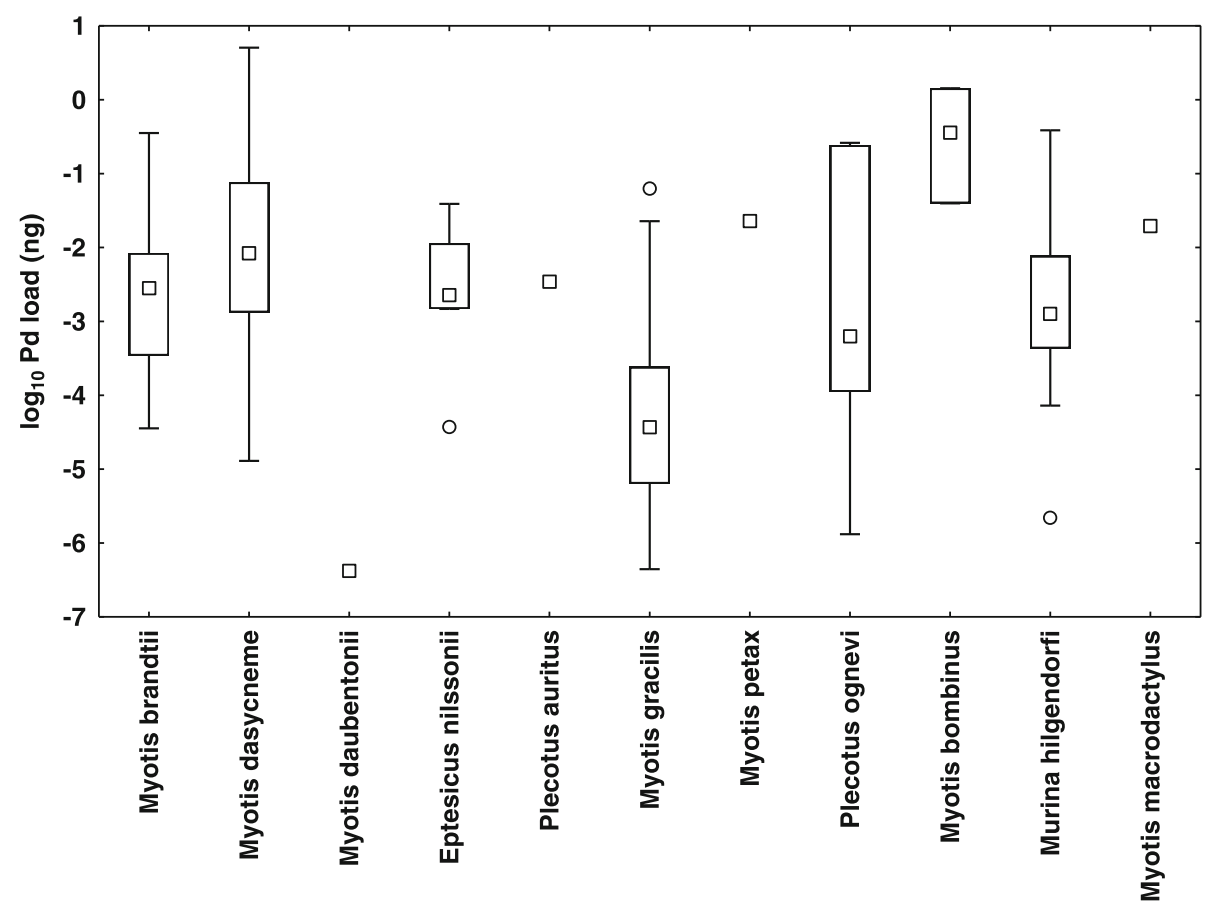

Fig. 5 Infection intensity, measured as fungal load in nanograms on a $\log _{10}$ scale, for Pseudogymnoascus destructans positive bats. Explanation: mid-point = median; box = inter-quartile range; whiskers = non-outlier minimum $/$ maximum range; dots = outliers

In contrast with sites in North America, P. destructans in the Palearctic region does not appear to be associated with dramatic bat mortalities [15, 19, 21], despite the number of $P$. destructans or WNS positive bat species being higher in the Palearctic than Nearctic (Additional file 2: Table S1). As previously predicted by Zukal et al. [40], three Asian vespertilionid bat species were newly confirmed with pathognomonic skin lesions induced by $P$. destructans infection in the present study (e.g. Fig. 4b, c). Paired data on identification of $P$. destructans with qPCR and WNS diagnostics on histopathology, supported with host molecular genetic phylogeny from the Eastern Palearctic [45], indicates that WNS affects $M$. bombinus, M. brandtii, M. dasycneme, $M$. gracilis, M. petax, Eptesicus nilssonii, Murina hilgendorfi and Plecotus auritus in Russia. Both M. daubentonii and M. macrodactylus were found to be infected with $P$. destructans, though WNS has not yet been confirmed on histopathology. Russian Siberian bats invaded by the fungus show clearly visible orange-yellow fluorescence of wing membrane skin lesions under UV light, documenting that this diagnostic tool [23] is applicable throughout the known distribution range of the pathogen and, moreover, that Russian $P$. destructans strains hyperproduce vitamin $\mathrm{B}_{2}$, a WNS virulence factor [26].

The WNS fungus is a generalist pathogen of hibernating vespertilionid and rhinolophid bats [40]. Assuming that all bats (with species-specific behavioural and roosting variation) that enter a $P$. destructans-contaminated hibernaculum have an equal chance of exposure to the pathogen, prevalence (percentage of bats positive for the agent) documented in Russian bats should then be an indicator of a high environmental contamination level and exposure rate. In this study, fungal load, a function of variables such as the infectious dose, duration of infection and growth rate of the agent in given environmental conditions, showed site- and species-dependent differences. Bat hibernation in the Urals, Siberia and the Russian Far East lasts up to 7 months and is confined to underground shelters due to strong frosts during winter. Temperatures in such hibernacula do not exceed $5{ }^{\circ} \mathrm{C}$ throughout the year [33-36]; hence, Russian bats should show lower fungal loads than European and North American bats as they hibernate under colder microclimatic conditions, which lead to slow temperature-dependent growth of the pathogen [12]. The prevalence of UV-documented skin lesions and histopathological positivity in this study signifies species susceptibility to infection. As the probability of serious wing membranes damage increases with increasing fungal load [25], and a lowered fungal load is linked with lower WNS impact (expressed as reduced UV fluorescent lesions, similar to [21]), we suggest that bats hibernating in such cold climatic conditions have a higher probability of surviving infection than elsewhere [46]. 


\section{Conclusion}

While it is not known how long the $P$. destructans fungal pathogen has been present in the Palearctic region, or whether there were periods of mass mortality associated with infection in the past (cf. [15]), our data suggest that its geographic expansion apparently covers the whole Palearctic niche of bat hibernation. The circumstances that influence its potential to cause morbidity and/or mortality in bats in Palearctic Russia are poorly understood; however, $P$. destructans is a significant disease-causing pathogen of hibernating bats, discovery of which warrants development of active surveillance programmes to better understand its epizootiology and to protect wildlife in general. This programme could be combined with testing for other agents of zoonotic importance, such as rabies.

\section{Additional files}

Additional file 1: Figure S1. Infection intensity, measured as fungal load in nanograms on a $\log _{10}$ scale, for particular regions. Explanation: mid-point = median; box = inter-quartile range; whiskers $=$ non-outlier minimum/maximum range; dots = outliers; stars = extremes.

(DOCX $21 \mathrm{~kb}$ )

Additional file 2: Table S1. Bat species from Palearctic and Nearctic regions with confirmed WNS or Pseudogymnoascus destructans infection. Summarized from [10, 16, 19, 21, 40, 47]. (XLSX 13 kb)

Additional file 3: Table S2. Datasets used and analyzed during the current study and not included in Tables 1, 2 and 3. (XLSX 31 kb)

\section{Abbreviations}

MCMC: Markov chain Monte Carlo; UV: Ultraviolet; WNS: White-nose syndrome

\section{Acknowledgements}

We would like to thank Masha Orlova Jr., Alexander Osintsev, Alexander Stashkin and Julia Kosheleva for their help with field research. We are grateful to Dr. Kevin Roche for his correction and improvement of the English text.

\section{Funding}

This research was supported by the Grant Agency of the Czech Republic (Grant No. 17-20286S) and through institutional support from the Institute of Vertebrate Biology of the Czech Academy of Sciences, v.v.i. (RVO: 68081766). The funders had no role in the study design, data analysis, and decision to publish, or preparation of the manuscript.

\section{Availability of data and materials}

Any datasets used and analyzed during the current study are in Tables 1, 2 and 3. Supporting data accompany this paper in Additional files as Additional files 2 and 3: Tables S1 and S2.

\section{Authors' contributions}

$J P$ and $J Z$ designed the study and participated in field research, with help from $H B, A B, V K, N M, O O, V P, A S, M T$. JP, VK and $M H$ performed the laboratory analyses. JZ and NM analysed the data. JZ, JP and VK wrote the manuscript, with contributions from all authors. All authors read and approved the final manuscript.

\section{Ethics approval}

Monitoring and collection of tissue samples from bats was approved by the Institute of Plant and Animal Ecology, Ural Division of the Russian Academy of Sciences (No. 16353-2115/325), the Institute of Biology and Soil Science, Far East Branch of the Russian Academy of Sciences (No. 16147/329), Tyumen State University (No. 06/162) and the Federal State Budgetary Institution "Western Baikal Protected Areas, Zapovednoe Pribaikalye".
Consent for publication

Not applicable.

\section{Competing interests}

The authors declare that they have no competing interests.

\section{Publisher's Note}

Springer Nature remains neutral with regard to jurisdictional claims in published maps and institutional affiliations.

\section{Author details}

${ }^{1}$ Department of Ecology and Diseases of Game, Fish and Bees, University of Veterinary and Pharmaceutical Sciences Brno, Palackého tř. 1946/1, 612 42 Brno, Czech Republic. ${ }^{2}$ Institute of Vertebrate Biology of the Czech Academy of Sciences, v.v.i., Květná 8, 60365 Brno, Czech Republic. ${ }^{3}$ Institute of Botany and Zoology, Masaryk University, Kotlářská 267/2, 61137 Brno, Czech Republic. ${ }^{4}$ Irkutsk State Medical University, Krasnogo Vosstania street 1, Irkutsk, Russian Federation664003. ${ }^{5}$ Institute of Biostatistics and Analyses, Masaryk University, Kamenice 126/3, 62500 Brno, Czech Republic. ${ }^{6}$ International Complex Research Laboratory for Study of Climate Change, Land Use and Biodiversity, Tyumen State University, Volodarckogo 6, 625003 Tyumen, Russia. ${ }^{7}$ Department of Biochemistry, Ural State Medical University, Repina 3, 620014 Ekaterinburg, Russia. ${ }^{8}$ Western Baikal protected areas, Federal State Budgetary Institution "Zapovednoe Pribaikalye", Baikalskaya st. 291B, 664050 Irkutsk, Russia. ${ }^{9}$ Institute of Biology and Soil Science, Far East Branch of the Russian Academy of Sciences, Pr-t 100-letiya Vladivostoka 159, 690022 Vladivostok, Russia.

Received: 22 March 2018 Accepted: 10 June 2018

Published online: 18 June 2018

\section{References}

1. Pikula J, Treml F, Beklová M, Holešovská Z, Pikulová J. Ecological conditions of natural foci of tularaemia in the Czech Republic. Eur J Epidemiol. 2003;18:1091-5.

2. Rosenthal J. Climate change and the geographic distribution of infectious diseases. Eco Health. 2009:6:489-95.

3. Bandouchova H, Bartonička T, Berkova H, Brichta J, Kokurewicz T, Kovacova V, Linhart P, Piacek V, Pikula J, Zahradníková A Jr, Zukal J. Alterations in the health of hibernating bats under pathogen pressure. Sci Rep. 2018;8:6067.

4. Swaminathan A, Viennet E, McMichael AJ, Harley D. Climate change and the geographical distribution of infectious diseases. In: Petersen $E$, Chen LH, Schlagenhauf-Lawlor P, editors. Infectious diseases: a geographic guide: John Wiley \& Sons Ltd; 2017. p. 470-80

5. Tack AJ, Thrall PH, Barrett LG, Burdon JJ, Laine A-L. Variation in infectivity and aggressiveness in space and time in wild host-pathogen systems causes and consequences. J Evol Biol. 2012;25:1918-36.

6. Jones KE, Patel NG, Levy MA, Storeygard A, Balk D, Gittleman JL, Daszak P. Global trends in emerging infectious diseases. Nature. 2008;451:990-3.

7. Calisher $\mathrm{CH}$, Childs JE, Field HE, Holmes KV, Schountz T. Bats: important reservoir hosts of emerging viruses. Clin Microbiol Rev. 2006;19:531-45.

8. Gargas A, Trest MT, Christensen M, Volk TJ, Blehert DS. Geomyces destructans sp. nov associated with bat white-nose syndrome. Mycotaxon. 2009;108:147-54.

9. Minnis AM, Linder DL. Phylogenetic evaluation of Geomyces and allies reveals no close relatives of Pseudogymnoascus destructans, comb nov, in bat hibernacula of eastern North America. Fungal Biol. 2013;117:638-49.

10. Blehert DS, Hicks AC, Behr M, Meteyer CU, Berlowski-Zier BM, Buckles EL, Coleman JT, Darling SR, Gargas A, Niver R, Okoniewski JC, Rudd RJ, Stone WB. Bat white-nose syndrome: an emerging fungal pathogen? Science. 2009;323:227

11. Frick WF, Pollock JF, Hicks AC, Langwig KE, Reynolds DS, Turner GG, Butchkoski CM, Kunz TH. An emerging disease causes regional population collapse of a common north American bat species. Science. 2010;329:679-82

12. Verant ML, Boyles JG, Waldrep W Jr, Wibbelt G, Blehert DS. Temperaturedependent growth of Geomyces destructans, the fungus that causes bat white-nose syndrome. PLoS One. 2012;7:e46280.

13. Marroquin CM, Lavine JO, Windstam ST. Effect of humidity on development of Pseudogymnoascus destructans, the causal agent of bat white-nose syndrome. Northeast Nat. 2017;24:54-64. 
14. Perry RW. A review of factors affecting cave climates for hibernating bats in temperate North America. Environ Rev. 2012;21:28-39.

15. Martínková N, Bačkor P, Bartonička T, Blažková P, Červený J, Falteisek L, Gaisler J, Hanzal V, Horáček D, Hubálek Z, Jahelková H, Kolařík M, Korytár L, Kubátová A, Lehotská B, Lehotský R, Lučan RK, Májek O, Matějů J, Řehák Z, Šafár J, Tájek P, Tkadlec E, Uhrin M, Wagner J, Weinfurtová D, Zima J, Zukal J, Horáček I. Increasing incidence of Geomyces destructans fungus in bats from the Czech Republic and Slovakia. PLoS One. 2010;5:e13853.

16. Wibbelt G, Kurth A, Hellmann D, Weishaar M, Barlow A, Veith M, Pruger J, Gorfol T, Grosche L, Bontadina F, Zophel U, Seidl H-P, Cryan PM, Blehert DS. White-nose syndrome fungus (Geomyces destructans) in bats, Europe. Emerg Infect Dis. 2010;16:1237-43.

17. Puechmaille SJ, Wibbelt G, Korn V, Fuller H, Forget F, Mühldorfer K, Kurth A, Bogdanowicz W, Borel C, Bosch T, Cherezy T, Drebet M, Görföl T, Haarsma AJ, Herhaus F, Hallart G, Hammer M, Jungmann C, Le Bris Y, Lutsar L, Masing M, Mulkens B, Passior K, Starrach M, Wojtaszewski A, Zöphel U, Teeling EC. Pan-European distribution of white-nose syndrome fungus (Geomyces destructans) not associated with mass mortality. PLoS One. 2011;6:e19167.

18. Pikula J, Bandouchova H, Novotny L, Meteyer CU, Zukal J, Irwin NR, Zima J, Martínková N. Histopathology confirms white-nose syndrome in bats in Europe. J Wildl Dis. 2012;48:207-11.

19. Hoyt JR, Sun K, Parise KL, Lu G, Langwig KE, Jiang T, Yang S, Frick WF, Kilpatrick AM, Foster JT, Feng J. Widespread bat white-nose syndrome fungus, northeastern China. Emerg Infect Dis. 2016;22:140-2.

20. Lorch JM, Palmer JM, Lindner DL, Ballmann AE, George KG, Griffin K, Knowles S, Huckabee JR, Haman KH, Anderson CD, Becker PA, Buchanan JB, Foster JT, Blehert DS. First detection of bat white-nose syndrome in western North America. mSphere. 2016;1:e00148-16.

21. Zukal J, Band’ouchová H, Brichta J, Cmokova A, Jaroň KS, Kolařík M, Kovacova V, Kubatova A, Novakova A, Orlov O, Pikula J, Presenik P, Suba J, Zahradnikova A, Martínková N. White-nose syndrome without borders: Pseudogymnoascus destructans infection tolerated in Europe and Palearctic Asia but not in North America. Sci Rep. 2016;6:19829.

22. Shuey MM, Drees KP, Lindner DL, Keim P, Foster JT. Highly sensitive quantitative PCR for the detection and differentiation of Pseudogymnoascus destructans and other Pseudogymnoascus species. App Environ Microbiol. 2014;80:1726-31

23. Turner GG, Meteyer CU, Barton H, Gumbs JF, Reeder DA, Overton B, Bandouchova H, Bartonička T, Martínková N, Pikula J, Zukal J, Blehert DS. Nonlethal screening of bat-wing skin with the use of ultraviolet fluorescence to detect lesions indicative of white-nose syndrome. J Wildl Dis. 2014;50:566-73.

24. Bandouchova H, Bartonicka T, Berkova H, Brichta J, Cerny J, Kovacova V, Kolarik M, Kollner B, Kulich P, Martínková N, Rehak Z, Turner GG, Zukal J, Pikula J. Pseudogymnoascus destructans: evidence of virulent skin invasion for bats under natural conditions, Europe. Transbound Emerg Dis. 2015;62:1-5.

25. Pikula J, Amelon SK, Bandouchova H, Bartonicka T, Berkova H, Brichta J, Hooper S, Kokurewicz T, Kolarik M, Kollner B, Kovacova V, Linhart P, Piacek V, Turner GG, Zukal J, Martínková N. White-nose syndrome pathology grading in Nearctic and Palearctic bats. PLoS One. 2017;12:e018043.

26. Flieger M, Bandouchova H, Cerny J, Chudickova M, Kolarik M, Kovacova V, Martínková N, Novak P, Sebesta O, Stodulkova E, Pikula J. Vitamin B2 as a virulence factor in Pseudogymnoascus destructans skin infection. Sci Rep. 2016;6:33200

27. Campana MG, Kurata NP, Foster JT, Helgen LE, Reeder DAM, Fleischer RC, Helgen KM. White-nose syndrome fungus in a 1918 bat specimen from France. Emerg Infect Dis. 2017;23:1611-2.

28. Zahradníková A Jr, Kovacova V, Orlova MV, Orlov OL, Martínková N, Piacek V, Zukal J, Pikula J. Historic and geographic surveillance of Pseudogymnoascus destructans possible from collections of bat parasites. Transbound Emerg Dis. 2018;65:303-8.

29. Schindelin J, Rueden CT, Hiner MC, Eliceiri KW. The ImageJ ecosystem: an open platform for biomedical image analysis. Mol Reprod Dev. 2015;82:518-29.

30. Tougard C, Delefosse T, Hanni C, Montgelard C. Phylogenetic relationships of the five extant Rhinoceros species (Rhinocerotidae, Perissodactyla) based on mitochondrial cytochrome $b$ and 125 rRNA genes. Mol Phylogenet Evol. 2001;19:34-44.

31. Katoh K, Standley DM. MAFFT multiple sequence alignment software version 7: improvements in performance and usability. Mol Biol Evol. 2013;30:772-80
32. Ronquist $F$, Teslenko M, van der Mark P, Ayres DL, Darling A, Hohna S, Larget B, Liu L, Suchard MA, Huelsenbeck JP. MrBayes 32: efficient Bayesian phylogenetic inference and model choice across a large model space. Syst Biol. 1990;61:539-42.

33. Bolshakov VN, Orlov OL, Snitko VP. Letučije myši Urala. Akadem kniga Jekatěrinburg; 2005. p. 176. (In Russian).

34. Botvinkin AD. Bats in the Lake Baikal region (biology, observation methods, protection). Irkutsk: Veter Stranstviy; 2002. p. 208. (In Russian).

35. Tiunov MP. Distribution of the bats in Russian Far East (problems and questions). In: Proceedings of the Japan-Russia Cooperation Symposium on the Conservation of the Ecosystem in Okhotsk. Published by Office of "Japan-Russia Cooperative Symposium on the Conservation of the Ecosystem in Okhotsk", Sapporo, Japan; 2011. p. 359-369.

36. Tiunov MP. Bats of Russian Far East. Vladivostok: Dalnauka; 1997. p. 134. (in Russian with English summary).

37. Pavia-Cardoso MDN, Morinha F, Barros P, Vale-Goncalves $H$, Coelho AC, Fernandes L, Travassos P, Faria AS, Bastos E, Santos N, Cabral JA. First isolation of Pseudogymnoascus destructans in bats from Portugal. Eur J Wildl Res. 2014;60:645-9.

38. Pavlinić I, Đaković M, Lojkić I. Pseudogymnoascus destructans in Croatia confirmed. Eur J Wildl Res. 2015;61:325-8.

39. Ransome RD. The natural history of hibernating bats. London: Christopher Helm; 1990. p. 256.

40. Zukal J, Bandouchova H, Bartonička T, Berkova H, Brack V, Brichta J, Dolinay M, Jaroň KS, Kovacova V, Kovařík M, Martínková N, Ondráček K, Řehák Z, Turner GG, Pikula J. White-nose syndrome fungus: a generalist pathogen of hibernating bats. PLoS One. 2014;9:e97224.

41. Ruf T, Geiser F. Daily torpor and hibernation in birds and mammals. Biol Rev. 2015;90:891-926.

42. Barlow AM, Worledge L, Miller H, Drees KP, Wright P, Foster JT, Sobek C, Borman AM, Fraser M. First confirmation of Pseudogymnoascus destructans in British bats and hibernacula. Vet Rec. 2015;177:73.

43. Meteyer CU, Buckles EL, Blehert DS, Hicks AC, Green DE, Shearn-Bochsler V, Thomas NJ, Gargas A, Behr MJ. Histopathologic criteria to confirm whitenose syndrome in bats. J Vet Diag Invest. 2009;21:411-4.

44. Davy CM Donaldson ME, Rico Y, Lausen CL, Dogantzis K, Ritchie K, Willis CKR, Burles DW, Jung TS, McBurney S, Park A, McAlpine DJ, Vanderwolf KF Kyle CJ. Prelude to a panzootic: gene flow and immunogenetic variation in northern little brown myotis vulnerable to bat white-nose syndrome. FACETS. 2017;2:690-714

45. Ruedi M, Stadelmann B, Gager Y, Douzery EJP, Francis CM, Lin LK, GuillénServent A, Cibois A. Molecular phylogenetic reconstructions identify East Asia asthe cradle for the evolution of the cosmopolitan genus Myotis (Mammalia, Chiroptera). Mol Phylogenet Evol. 2013;69:437-49.

46. Grieneisen LE, Brownlee-Bouboulis SA, Johnson JS, Reeder DM. Sex and hibernaculum temperature predict survivorship in white-nose syndrome affected little brown myotis (Myotis lucifugus). R Soc Open Sci. 2015:2:140470.

47. US Fish Wildlife Service Online [2017/11/28]. https://www. whitenosesyndrome.org/about/bats-affected-wns.

Ready to submit your research? Choose BMC and benefit from:

- fast, convenient online submission

- thorough peer review by experienced researchers in your field

- rapid publication on acceptance

- support for research data, including large and complex data types

- gold Open Access which fosters wider collaboration and increased citations

- maximum visibility for your research: over $100 \mathrm{M}$ website views per year

At BMC, research is always in progress.

Learn more biomedcentral.com/submissions 